\title{
Seroprevalence of Trypanosoma cruzi Infection in Students at the Seven-Fourteen Age Range, Londrina, PR, Brazil, in 1995
}

\author{
Ana Maria Bonametti/ ${ }^{+}$, Adauto Castelo Filho*, Luiz Roberto Ramos*, \\ Eide Dias Camargo**, Paulo Mutuko Nakamura**, José Luís da Silveira Baldy, \\ Tiemi Matsuo
}

Centro de Ciências da Saúde, Universidade Estadual de Londrina, Rua Roberto Koch 40, 86038-440 Londrina,

PR, Brasil *Escola Paulista de Medicina, Universidade Federal de São Paulo, Rua Botucatu 685, 04023-062

São Paulo, SP, Brasil **Seção de Sorologia, Instituto Adolfo Lutz, Av. Dr. Arnaldo 351, 01246-902

São Paulo, SP, Brasil

Seropositivity for Chagas disease was evaluated in 834 children aged between 7 and 14 from the Municipal Teaching System in the district of Londrina, State of Paraná. A seroprevalence rate of 0.1\% was found through the use of an indirect immunofluorescent test and an enzyme-linked immunosorbent assay. This low rate of seroprevalence provides evidence that the vectorial transmission of Chagas disease has been eliminated in Londrina. The main reason for the elimination of vectorial transmission of Trypanosoma cruzi infection, as evaluated by serological tests, may be a remarkable change in the economic structure of the northern region of Paraná in the 1960's. At that time coffee production was almost completely replaced by soy beans, wheat and grazing in the rural areas. This change deeply affected the rural ecology and caused an exodus of the population from rural to urban areas as well as a decrease in the total number of the population of that region. The measures introduced for controlling the disease through the Program of Chagas Disease Control established by the Fundação Nacional de Saúde of the Brazilian Ministry of Health, certainly, had a positive impact on the reduction of American trypanosomiasis prevalence in the area under study. However, it does not seem that this was the most relevant factor responsible for the elimination of vectorial transmission of Chagas disease in Londrina.

Key words: Chagas disease - epidemiology - control program - Brazil

Trypanosoma cruzi is part of an exclusively American ecosystem and is found in large extensions of this continent stretching from southern United States, where sporadic cases of Chagas disease have been reported, to southern Argentina and Chile. Although data concerning the prevalence and morbidity of Chagas disease increased in the 1980 's, it is still difficult to accurately establish its geographical distribution as well as its prevalence in Latin America (Rassi et al. 1989, Rey 1991, WHO 1991, Wanderley \& Corrêa 1995).

In the American continent the prevalence of human infection by $T$. cruzi is estimated at 16 to 18 million cases, although an additional 90 million, i.e., $25 \%$ of the population of the continent is

\footnotetext{
This work has been supported by a grant from International Clinical Epidemiology Network.

${ }^{+}$Corresponding author. Fax: +55-43-337.5100. E-mail: bonamet@inbrapenet.com.br

Received 21 January 1998

Accepted 31 August 1998
}

exposed to the risk of being infected. Among the 211 million inhabitants of the American Continent in the South Cone, some 11 million are infected and around 54 million are under the risk of being infected, representing $31 \%$ of the population. Based upon a number of studies carried out in Brazil, it is estimated that about $30 \%$ of the infected population present symptoms and signs of the disease. Thus, it is assumed that approximately 4.8 to 5.4 million people present clinical manifestations attributed to Chagas disease. According to the World Health Organization (WHO) more than 50,000 people a year die of Chagas disease (Situación de la enfermedad de Chagas en las Americas 1984, WHO 1986, 1991, Chagas disease 1990, Rey 1991, Chuit 1993, Kirchhoff 1993, 1996, Moncayo 1993, Elimination of transmission of Chagas disease in southernmost Latin America 1994, Guariento 1994, Wanderley 1994, Corrêa et al. 1996, Ferreira \& Ávila 1996, Meyer et al. 1996).

In order to obtain information concerning the distribution of $T$. cruzi infection in the country, a wide serological survey on the prevalence of Chagas disease was carried out in Brazil from 1975 
to 1981 , under the coordination of Conselho Nacional de Pesquisa (CNPq) and with the collaboration of Superintendência de Campanhas (Sucam) of the Brazilian Ministry of Health. The survey was restricted to the rural population and the estimated prevalence of positive reactions was recorded as $4.2 \%$ in Brazil as a whole. The states with the highest rates of positive reaction were Rio Grande do Sul (8.8\%), Minas Gerais, (8.8\%) and Goiás (7.4\%). In the State of Paraná and in the district of Londrina the rates of seropositivity were $4 \%$ and $3.7 \%$, respectively (Brasil, Ministério da Saúde 1979, Camargo et al. 1984).

The $4 \%$ prevalence in Paraná corresponds to an estimated 166,511 people infected by $T$. cruzi in a population of 4.164,943 inhabitants from the rural area. These figures rank Paraná as the fourth state in terms of the estimated number of infected patients in Brazil, being surpassed only by Minas Gerais, Bahia, and Rio Grande do Sul (Toledo et al. 1997).

Recent data published by the Brazilian Program for the Control of Chagas Disease (PCDCh) in Brazil - a signatory of the "South Cone Iniciative" for the reduction of the transmission by means of spraying insecticides in residences and through the maintenance of serological tests in blood banks in six countries of South America - indicate that the transmission eradication in Brazil is imminent (Chagas success in Brazil and Colombia 1996). The virtual elimination of $T$. infestans in Brazil is demonstrated not only by the entomological indicators adopted but also by the results of the serological surveys carried out with groups of young people, which confirm the impact of the preventive actions on the transmission. Data relating to morbidity and mortality also strongly, indicate that the vectorial control has lead to a distinct reduction in the number of cases of Chagas disease and of deaths caused by that disease (Dias 1991, Silveira \& Rezende 1994, Dias \& Gontijo 1995).

This study evaluates the prevalence of the infection by $T$. cruzi - using two serological tests enzyme-linked immunosorbent assay (ELISA) and indirect immunofluorescence (IFI) - in children aged between 7 and 14 (students of elementary school from the municipal educational system) living in both urban and rural areas of Londrina.

\section{MATERIALS AND METHODS}

The target population comprised students of the basic cycle (elementary school) of the Municipal School System of Londrina.

The students sample was simple casual stratified (urban and rural areas).

For a population of 26,573 children aged between 7 and 14, living in Londrina, with an esti- mated prevalence of positivity for infection by $T$. cruzi reaching 0.035 (with an error margin of 0.0125 ), the calculated size of the sample was 805 students, with a confidence interval of $95 \%$. In order to decrease the error margin, 834 students were evaluated. Data on age, sex, address and place of birth were collected and recorded.

The decision to study a number of rural area children twice as large as those of the urban area was based on the assumption that the prevalence of seropositivity for T. cruzi infection in those children would be higher than that observed in children from the urban area of the district.

Due to the ease with which the tests could be carried out, the easy transportation of the material and in order to reduce of costs, a digital collection of blood was made, (upon the permission of the children's parents or guardians) with the use of a paper filter as support, according to the standardized technique developed by Camargo et al. (1984). The reliability and quality of this method has been demonstrated by a number of studies previously performed in our country. The paper filter utilized was the 3 MM CHR (Whatman Laboratory Division Maidstone, England).

The immunological diagnosis of the infection by $T$. cruzi was performed by researchers of the Adolfo Lutz Institute, São Paulo, who employed the IFI and ELISA techniques. The ELISA for detecting class IgG antibodies was carried out according to the method described by Voller (1975). The aliquots were tested at four dilutions (1/64 to $1 / 512$ ) and a reactive dilution ${ }^{3} 1 / 128$ was considered as meaningful. The cut-off point of the test was 0.250 .

The IFI was carried out according to the method of Fuchs et al. (1980), and the results presenting a value of ${ }^{3} 1 / 32$ were considered meaningful. The sensitivity and specificity of both reactions (ELISA and IFI) are $98.5 \%$ and $95.2 \%$, and $95.2 \%$ and $96.3 \%$, respectively.

The students who presented two positive reactions after confirmation were considered seroreactive.

In order to confirm the results obtained from the serological tests of the students, venous blood from the only seropositive child was collected and re-analyzed using the same techniques (IFI and ELISA). In addition, blood samples of all other members of that child's family were collected through venous puncture and processed by IFI and ELISA.

A descriptive statistic was used in order to calculate the averages and standard deviations of the students' age, confidence intervals of the proportions and variables distribution in charts. 


\section{RESULTS}

The average age was $9.1 \pm 1.6$ years. Out of 834 students, $424(50.8 \%)$ were male.

With regards to their address, $589(70.6 \%)$ students were from the rural area and $245(29.3 \%)$ from the urban area of Londrina. As for their place of birth, most of them, i. e., 652 (78.2\%) students, were born in the district and $182(21.8 \%)$ were migrant children.

Out of 834 blood samples examined, only one was seropositive both for IFI and ELISA (Table I). That child was born on 4 November 1984 and had been living in the country area of Londrina since birth. The mother was born in an endemic area of Chagas disease in Minas Gerais and lived there for 18 years prior to moving to the rural area of Londrina. The mother's health records, obtained from the Hospital Universitário Regional do Norte do Paraná in Londrina, revealed that she was seropositive for $T$. cruzi infection (indirect immunofluorescent and complement fixation techniques) when the child was born. These tests were also positive with a sample of cord blood.

The confirmatory serologic tests of the child revealed titers of 1:2048 for ELISA and 1:512 for IFI. The confirmatory tests in the mother presented the same titers. The father and the two brothers of the child were non-reagent by the same two techniques.

\section{TABLE I}

Distribution of the students according to the test results of indirect immunofluorescence (IFI) and enzyme-linked immunosorbent assay (ELISA) for the diagnosis of Trypanosoma cruzi infection

\begin{tabular}{lrrc}
\hline IFI and ELISA & No. & $\%$ & $\begin{array}{c}\text { Reliable interval } \\
(95 \%)\end{array}$ \\
\hline Reagents & 1 & 0.1 & $0-0.7$ \\
Non-reagents & 833 & 99.9 & $99.3-100$ \\
\hline Total & 834 & 100 & \\
\hline
\end{tabular}

In Table II it can be observed that the serological inquiry (IFI) for the diagnosis of infection by T. cruzi, carried out between 1976 to 1979 in Paraná examining a sample of 1,318 residents in the rural area of Londrina, revealed seropositivity for 46 persons. Although the total number of persons in terms of age range is not available, the study revealed that only two children in the 7 - 14 age range were serum reactive (Brasil, Ministério da Saúde 1979).

\section{DISCUSSION}

Entomological evaluations have proved that vectorial transmission of the T. cruzi infection has effectively been interrupted in Londrina (Brasil, Ministério da Saúde 1996). However, we have not found any report on serological studies carried out with children which objectively shows the impact of PCDCh and other factors on that occurrence. Thus we decided to perform a serological survey of students with ages ranging from 7 to 14 , living in both rural and urban areas of Londrina.

Out of 834 children submitted to serological examination for the diagnosis of T. cruzi infection (employing the ELISA and IFI techniques), only one child was positive, corresponding to a positivity rate of only $0.1 \%(0 \%-0.7 \%$ with $95 \%$ reliability). If we consider just the portion of the children residing in the rural area of the district, the rate was $0.2 \%(0 \%-0.9 \%)$ also with $95 \%$ reliability.

We could not ignore the possibility that the child had been infected by congenital transmission. There was some indirect evidence that favored this possibility, including the fact that the mother of that child was infected when the child was born; the positivity of serologic tests for T. cruzi infection in blood samples obtained from umbilical cord by ELISA and IFI techniques; and the presence of advanced cardiomyopathy in the infected child. Triatomas density in the area where the child had lived since birth had always been very low (since 1983) (Brasil, Ministério da Saúde 1977, 1996),

\section{TABLE II}

Distribution of seropositive patients for Trypanosoma cruzi infection in serological tests of indirect immunofluorescence carried out in the rural zone of the district of Londrina, Paraná, according to the age range (1976-1979)

\begin{tabular}{|c|c|c|c|c|c|c|c|c|}
\hline \multirow{3}{*}{$\begin{array}{l}\text { Serological } \\
\text { test results }\end{array}$} & \multicolumn{5}{|c|}{ Age range (Years) } & & & \multirow{3}{*}{$\begin{array}{c}\text { Reliable } \\
\text { interval } \\
(95 \%)\end{array}$} \\
\hline & $1-6$ & $7-14$ & $15-29$ & $30-44$ & 345 & \multicolumn{2}{|c|}{ Total } & \\
\hline & No. & No. & No. & No. & No. & No. & $\%$ & \\
\hline Reagents & 0 & 2 & 15 & 16 & 13 & 46 & 3.5 & $2.6-4.6$ \\
\hline Non-reagents & $a$ & $a$ & $a$ & $a$ & $a$ & 1,272 & 96.5 & $95.4-97.4$ \\
\hline Total & $a$ & $a$ & $a$ & $a$ & $a$ & 1,318 & 100 & \\
\hline
\end{tabular}

a: not available. Source: Health Ministry: Public Health Campaign, Regional Board of Paraná, 1979. 
and no evidence of the presence of triatomas had been detected by technicians of the Fundação Nacional de Saúde (FNS).

When our results were compared with those obtained by the National Serological Inquiry carried out from 1976 to 1979 in the general rural population, it was shown that out of 589 children from the rural area, only one was seropositive for T. cruzi infection, while in the previous inquiry, out of the total 1,318 persons of all ages, 46 were seropositive. It is important to notice that out of this number only two belonged to the 7 to 14 age range group (Brasil, Ministério da Saúde 1979). As the total data from that inquiry as to age group are not available, it is not possible to perform a comparative statistical analysis. However, the results indicate that, even at that time (before starting PCDCh) the rate of seropositivity for T. cruzi infection in children aged between 7 and 14 was already low, in common with what was demonstrated in our study.

The results of our research were similar to those obtained in studies carried out in different regions of Brazil and in the country as a whole. In the whole country the serum prevalence of $T$. cruzi infection in children aged between 7 and 14 was recorded as $2.4 \%$ in 1980 . However, by 1994 , this prevalence had reduced to only $0.1 \%$, corresponding to a 95\% reduction of American trypanosomiasis incidence in that age group (Silveira \& Rezende 1984, Chagas success in Brazil and Colombia 1996).

According to Carneiro and Antunes (1994b), some studies carried out in Brazil, in areas under PCDCh intervention, demonstrated that there was a decrease in the level of $T$. cruzi infection in the human population within the area under evaluation. Some workers consider that this reduction was directly connected with the control actions developed; while some other researches contend that the observed decrease was due mainly to the social, economic and cultural changes that occurred during the intervention period.

Carneiro and Antunes (1994a, b) evaluated the efficiency of PCDCh in a study carried out in Minas Gerais. The PCDCh efficiency was estimated by comparison with the results obtained by the National Serological Inquiry (1975-1980) performed before the program started. According to these authors the results showed an association between the PCDCh actions and the decrease in T. cruzi infection which was evaluated through serological tests.

The FNS Minas Gerais Program has been performing serological tests for the diagnosis of American trypanosomiasis in students of the rural area aged between 7 and 14 with the purpose of analyzing the results obtained by the PCDCh, preferably in the districts already under epidemiological surveillance. Preliminary results from this study suggest effectiveness of PCDCh in Minas Gerais (Azeredo et al. 1997). According to Moreno et al. (1996) comparison of the results from the inquiry carried out with students with the results obtained by the National Serological Inquiry reveals differences in the relative values, demonstrating a decrease of more than $90 \%$. That decrease confirms, therefore, the success of the PCDCh program in reducing vectorial transmission in the group of children born after the program implantation.

According to Silva $(1981,1990)$, the analysis of the causes of the disappearance of endemic Chagas disease in São Paulo indicated that the rural population decrease, and the consequent reduction in the number of residences was a relevant factor to the disappearance of Chagas disease in that state. Moreover, in Silva's opinion, some resistance to the elimination of endemic disease was observed in the areas of São Paulo where there was no decrease of rural population. Wanderley (1993) stated that the rural exodus was followed by the destruction of houses at that time, suggesting that the destruction was selective, that is, it happened in a sequence from the worst houses to those of a better standard, affecting primarily those houses inhabited by triatomas. Many authors consider that this factor, along with the direct action for the control of the vector, which were intensified in this period were extremely relevant to the process of interrupting the transmission of Chagas disease in São Paulo.

Silva (1996) claims that as has happened to many large urban centers of the country since the 1960 's, Londrina has also gone through an accelerated urbanization process. The population in the urban area increased from $47 \%$ in 1950 to nearly 95\% in 1995 (Table III). At present the population is concentrated mainly in the city with the remainder distributed throughout the various towns nearby following the same pattern as other small towns found in Paraná.

Table III shows that in 1970, although the rural population of the district of Londrina had already reached the highest point $(64,573$ persons) in absolute figures, the proportion of rural inhabitants had already decreased in relation to the number of inhabitants in the urban area. Furthermore, in 1980, there was a relevant reduction of the rural population not only as an absolute figure but also proportionally. At that time the annual growth rate of the district had already decreased in relation to the 70's and, especially, in relation to the 60's. These figures indicate that the coffee plantation declined, the consequent rural exodus and population defla- 
TABLE III

Evolution of population living in the district of Londrina in the years 1950, 1960, 1970, 1980, 1991 and 1995

\begin{tabular}{lcllcrc}
\hline Year & Urban & $\%$ & Rural & $\%$ & Total & Growth rate/year \\
\hline 1950 & 34,230 & 47.9 & 37,182 & 52.1 & 71,412 & - \\
1960 & 77,382 & 57.4 & 57,439 & 42.6 & 134,821 & 6.6 \\
1970 & 163,528 & 71.7 & 64,573 & 28.3 & 228,101 & 5.4 \\
1980 & 266,940 & 88.5 & 34,771 & 11.5 & 301,711 & 2.8 \\
1991 & 366,676 & 94 & 23,424 & 6 & 390,100 & 2.3 \\
1995 & 431,578 & 94.9 & 23,233 & 5.1 & 454,811 & -
\end{tabular}

Source: population - Census 1950 IBGE/Preliminary Synopsis of Census Demofigura; 1960/IBGE/Census Demofigure - 1970, 1980 and 1991; IBGE/IPPUL - estimate - 1995.

tion of the district that occurred at that time may have been the main reasons for the eradication $T$. cruzi vectorial transmission in Londrina. As PCDCh control measures were introduced after all those changes, our study suggests that their impact was less significant.

As stated by Silva (1981, 1990), it would be difficult or even impossible to assess the relative effect of the different factors involved in the extinction of endemic disease in São Paulo. That author pointed out that the specific combat activities were determined by politico-economical and technical-scientific injunctions, and the development that took place in the rural area of São Paulo was a result of those determinants. A campaign against a given disease as well as the rural exodus are both derived from the evolution of a society. When we analyze the disconnection of the relational system that allows the existence and the dissemination of the disease we must include the control actions along with other so called "social-economical" factors.

Through these considerations, one can conclude that the social, economical and ecological transformations that took place in São Paulo were similar to those that occurred in Paraná some decades later. In the period between 1940 and 1960, when the colonization and the coffee plantation were at their peak in Paraná, the coffee plantation in São Paulo was already in decline and the rural-urban exodus had already started. These transformations in Paraná had their start in the 1960's and reached their peak in the 1970's.

Although the methodology of our work does not allow us to have a full evaluation of the impact of the multiple factors involved in the elimination of vectorial transmission of infection by $T$. cruzi in Londrina, several facts suggest that the main causes for this elimination were the rural-urban exodus that took place in the 60's and 70's and the decrease in the population of the district. The lat- ter resulted from changes in the rural economy which turned from a predominant coffee production to the production of other crops such as soy beans and wheat that require a comparatively smaller labor force. This change led to an exodus from the rural areas and caused important ecological and social modifications in the rural setting. The resulting situation seems to have been the determining factor in the eradication of vectorial transmission of the Chagas disease in the district of Londrina.

\section{REFERENCES}

Azeredo BVM, Cabral AL, Moreira EF, Dias JCP 1997. Prevalência da infecção chagásica entre escolares da zona rural de Minas Gerais, entre 1989 e 1996. 33 Congresso da Sociedade Brasileira de Medicina Tropical, Belo Horizonte.

Brasil, Ministério da Saúde 1977. Superintendência de Campanhas de Saúde Pública. Diretoria Regional do Paraná. Registros sobre Doença de Chagas na Região de Londrina no Período de 1976 a 1977, Curitiba, 2 pp.

Brasil, Ministério da Saúde 1979. Superintendência de Campanhas de Saúde Pública. Diretoria Regional do Paraná. Inquérito Sorológico (Doença de Chagas) no Estado do Paraná (1976 a 1979), Curitiba, 8 pp.

Brasil, Ministério da Saúde 1996. Fundação Nacional de Saúde. Distrito Sanitário de Londrina. Relatório das Atividades Realizadas pelo Distrito Sanitário de Londrina, nos anos de 1983 a 1996 no Município de Londrina, Londrina, $2 \mathrm{pp}$.

Camargo ME, Silva GR, Castilho EA, Silveira AC 1984. Inquérito sorológico da prevalência de infecção chagásica no Brasil, 1975/1980. Rev Inst Med Trop São Paulo 26: 192-204.

Carneiro M, Antunes CMF 1994a. A quasi-experimental epidemiological model for evaluating public health programs: efficacy of a Chagas disease control program in Brazil. Bull WHO 72: 721-728.

Carneiro M, Antunes CMF 1994b. Avaliação de eficácia do Programa de Controle da Doença de Chagas: aspectos metodológicos. Cad Saúde Públ Rio de Janeiro 10 (Suppl. 2): 261-272. 
Chagas disease 1990. Wkly Epidemiol Rec 65: 257-264.

Chagas success in Brazil and Colombia 1996. TDR news 49: 3-4.

Chuit R 1993. Programa de eliminación y sistemas de información. Rev Soc Bras Med Trop 26 (Suppl. 3): 45-50.

Corrêa AD, Miranda Filho N, Siqueira-Batista R, Reis CLS, Vahia-Loureiro AM, Huggins DW 1996. Epidemiologia, p. 16-38. In R Siqueira-Batista, AD Corrêa, DW Huggins (eds), Moléstia de Chagas, Cultura Médica, Rio de Janeiro.

Dias JCP 1991. Chagas' disease control in Brazil: which strategy after the attack phase? Ann Soc Belge Med Trop 71 (Suppl.1): 75-86.

Dias JCP, Gontijo ED 1995. Epidemiologia da doença de Chagas, p. 5-8. In ECD Gontijo, MOC Rocha (eds), Manejo Clínico do Paciente Chagásico, Núcleo de Estudos em Doença de Chagas da Faculdade de Medicina da Universidade Federal de Minas Gerais, Belo Horizonte.

Elimination of Transmission of Chagas' Disease in Southernmost Latin America 1994. World Health Forum 15: 299-300.

Ferreira AW, Ávila SLM 1996. Doença de Chagas, p. 145-149. In AW Ferreira, SLM Ávila (eds), Diagnóstico Laboratorial das Principais Doenças Infecciosas e Auto-imunes, Guanabara Koogan, Rio de Janeiro.

Fuchs AP, Fioratti VL, Mello VA, Boainain E 1980. Diagnóstico sorológico na doença de Chagas. Estudo comparativo de diferentes técnicas. Rev Inst Med Trop São Paulo 22: 242-245.

Guariento ME 1994. Diagnóstico sorológico da doença de Chagas em Serviço de Hemoterapia - Aspectos controversos. Rev Soc Bras Med Trop São Paulo 27 (Suppl. 2): 124-125.

Kirchhoff LV 1993. Chagas disease. American trypanosomiasis. Infect Dis Clin N Am 7: 487-502.

Kirchhoff LV 1996. American trypanosomiasis (Chagas'disease). Gastr Clin N Am 25: 517-533.

Meyer MA, Teixeira MG, Pain JS, Silva LMV 1996. Mortalidade por doença de Chagas: evolução e distribuição no espaço urbano de Salvador, Bahia. IESUS 4: 21-29.

Moncayo A 1993. Prioridades de investigação. Rev Soc Bras Med Trop 26 (Suppl. 3): 65-71.

Moreno EC, Carneiro M, Antunes CMF 1996. Aspectos metodológicos do inquérito sorológico em escolares e estudo caso-controle aninhado para avaliação de eficácia do programa de controle da doença de Chagas. IESUS 5: 49-57.

Rassi A, Porto CC, Rezende JM 1989. Doença de Chagas, p. 247-263. In A Amato Neto, JLS Baldy (eds), Doenças Transmissíveis, 3 ed., Sarvier, São Paulo.

Rey L 1991. Trypanosoma cruzi e doença de Chagas: ecologia, epidemiologia e controle, p. 138-152. In L Rey, Parasitologia, 2 ed., Guanabara-Koogan, Rio de Janeiro.

Silva LJ 1981. Evolução da Doença de Chagas no Estado de São Paulo, PhD Thesis, USP, Ribeirão Preto, 188 pp.

Silva LJ 1990. Organização do espaço e doença, p. 159185. In Textos de Apoio. Epidemiologia 1, 2 ed., Abrasco, Rio de Janeiro.

Silva SF 1996. Da "pequena Londres" à grande Londrina, p. 3-7. In SF Silva, A Construção do S.U.S a Partir do Município, Hucitec, São Paulo.

Silveira AC, Rezende DF 1994. Epidemiologia e controle da transmissão vetorial da doença de Chagas no Brasil. Rev Soc Bras Med Trop 27 (Suppl. 3): 1122.

Situacion de la enfermedad de Chagas en las Americas 1984. Bol Of Sanit Panam 97: 159-165.

Toledo MJO, Kühl JB, Silva SV, Gasperi MV, Marques de Araújo S 1997. Estudo sobre triatomíneos e reservatórios silvestres de Trypanosoma cruzi no Estado do Paraná, Sul do Brasil. Resultados preliminares. Rev Soc Bras Med Trop 30: 197-203.

Voller A 1975. Microplate enzyme-linked immunosorbent assay for Chagas' disease. Lancet 22: 426-428.

Wanderley DMV 1993. Controle de Triatoma infestans no Estado de São Paulo. Rev Soc Bras Med Trop 26 (Suppl. 3): 17-25.

Wanderley DMV 1994. Controle da doença de Chagas. Rev Soc Bras Med Trop 27 (Suppl. 4): 728-732.

Wanderley DMV, Corrêa FMA 1995. Epidemiology of Chagas' heart disease. São Paulo Med J 113: 742749.

WHO - World Health Organization. Undp/World Bank 1986. Special program for research and training in tropical diseases. Research activities of the scientific working group (SWG) on Chagas' disease 19821985 of the Steering Committee (SC) to the Scientific and Technical Review Committee (STRC). Mem Inst Oswaldo Cruz 81 (Suppl.): 183-189.

WHO - World Health Organization 1991. Control of Chagas Disease, WHO Technical Report Series, 811, Geneva, 95 pp. 